\title{
Stock Returns Moderated Good Corporate Governance Mechanisms and Firm Value
}

\author{
Dhea Ramana Putri, Husnah Nur Laela Ermaya, Noegrahini Lastiningsih \\ Universitas Pembangunan Nasional (UPN) Veteran Jakarta, Indonesia \\ Email: dhea.ramana@upnvj.ac.id, husnah_ermaya@upnvj.ac.id, \\ noegrahini.lastiningsih@upnvj.ac.id
}

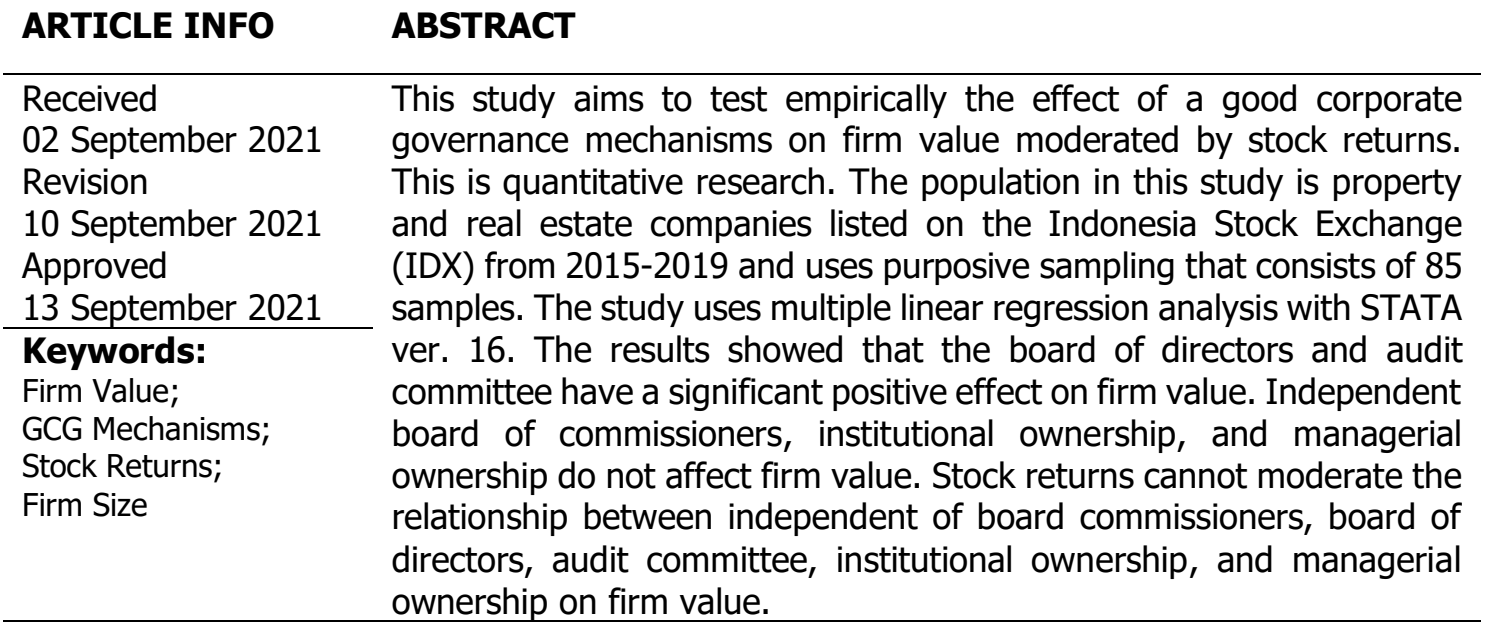

\section{INTRODUCTION}

Every company will have ambitions to get high firm value because this will represent shareholders' welfare (Hanafi \& Mamduh, 2008 p.85). The company's management will try to reveal information that investors like, especially when it comes to stock returns. This will generate public trust in the company and also increase the effectiveness of good corporate governance (GCG) according to standards.

GCG is a system that structures the relationships between company owners, management, employees, creditors, government, and shareholders (FCGI, 2002). GCG implementation is observed through a mechanism. The GCG mechanisms are expected to provide a balance for various interests in increasing firm value and maintaining the survival of the company in the long term, both for small and large companies.
Large companies show growth because they are better known by the public and have good performance quality so that the profits generated by the company are more stable than a small company. Therefore, investors' decisions will affect by those reasons.

Currently, the COVID-19 has hit several business sectors, one of which is the property \& real estate industry. The Central Statistics Agency published that Indonesia's GDP was at $-5.32 \%$ in the second quarter of 2020 . Property and real estate were some of the factors that contributed to the decline in economic growth in the second quarter. The contribution to GDP is still minimal when compared with ASEAN countries (Bisnis.com, 2020).

The property price index decreasing every year. This is due to a large number of positive cases of corona due to office clusters so that companies carry out Work from Home

$\begin{array}{ll}\text { How To Cite: } & \text { Putri, D. R., Ermaya, H. N. L., Lastiningsih, N. (2021) Stock Returns Moderated Good Corporate } \\ & \text { Governance Mechanisms And Firm Value. Journal of Social Science. 2(5). } \\ & \text { https://doi.org/10.46799/jss.v2i5.118 } \\ \text { E-Issn: } & \text { 2721-5202 } \\ \text { Published By: } & \text { Ridwan Institut }\end{array}$


(WFH) (CNBC Indonesia, 2020). Also, the Composite Stock Price Index (IHSG) decreased to $5.01 \%$ on March 19,2020 , so the IDX decided to temporarily suspend trading on the stock exchange (CNN Indonesia, 2020). This case is not only happening in Indonesia but also in New York. Simon Property Group stated that its occupancy rate decreased $1.5 \%$ from last year that caused its shares to drop to $55 \%$ (CNBC International, 2020).

Apart from the COVID-19 pandemic, there were corruption cases committed by Lippo Group Tbk in 2018 and PT Agung Podomoro Land Tbk in 2016. This case has violated the applicable code of ethics and law. Both cases were discovered by bribes made by the board of directors to local officials. From these two cases, it can be seen that large companies do not necessarily implement GCG properly. The implementation of the GCG mechanisms is expected to provide a balance for various interested parties so that it will affect public trust. If public trust decreases, it will be related to a decline in share prices, which will affect the value of the company.

(Bermundo et al., 2019) state the independent board of commissioners and board of directors have a significant positive relationship with firm value, while (Amaliyah \& Herwiyanti, 2019) say the opposite. (Dhamasanti \& Sudaryati, 2020) state that the audit committee has a significant positive effect on firm value, while (Agustina et al., 2020) otherwise. (Suhadak et al., 2019) and (Handayani, 2017) state that institutional and managerial ownership has a positive influence on firm value. (Agustina et al., 2020) and (Kartikasari et al., 2019) state otherwise. Based on the phenomena that have occurred and inconsistent previous research results, further research will be carried out on the relationship between the GCG mechanisms on firm value moderated by stock returns.

\section{A. Agency Theory}

Agency relation is the agreement of one or more people (principal) who are involved with other people (agents) in carrying out several services by appointing the decision-making authority on behalf of the principal to the agent (Jensen \& Meckling, 1976). When associated with this theory, human nature always focuses on itself, just thinks about the future, and tends to stay away from risks (Eisenhardt, 2018). Based on these characteristics, there is often a conflict of interest (agency problem) between the principal and the agent.

This theory also states that disputes between principals and agents arise due to differences in ownership and management of companies. One of the agency problems is information asymmetry. (Scott, 2015) divides information asymmetry into two types, namely adverse selection, and moral hazard.

\section{B. Signaling Theory}

Signal theory is a strategy carried out by high-ranking managers to differentiate their company from other companies (Spence, 1973). Signals are the company's way of providing clues to investors about the company's future predictions. The type of signal given is information about management's strategy in managing the company to realize the wishes of the shareholders.

Since there is an imbalance of information, companies submit reports to the outside. Information asymmetry between well-informed managers and shareholders who have little information underlies research into signal theory. Research conducted by (Ross, 1977) concluded that managers who owe more will provide a signal that will be trusted by the public. Investors will certainly be motivated to invest in companies that have a significant rate of return. The value of the company will be affected because the maximum return has an impact on the stock price. A high stock price is a positive signal, so investor confidence will also increase. 
1. The Relationship between the Independent Board of Commissioners and Firm Value

The independent board of commissioners whose task is to encourage the implementation of GCG in the company. The proper implementation of GCG will increase public trust. The public will invest in companies that implement GCG so that this will have an impact on increasing firm value through share prices. Therefore, this study suggests:

$\mathrm{H} 1$ : The independent board of commissioners has a significant positive effect on firm value.

2. The Relationship between the Board of Directors and Firm Value

The board of directors plays an important role in determining the company's performance. They are the parties who manage the company. The company management includes making strategies and policies regarding the sustainability of the company. Company management can run well if GCG is carried out properly. GCG is a pillar in preventing agency problems so that it can reduce monitoring costs which will have an impact on increasing firm value. Based on that explanation, researchers suggest: $\mathrm{H} 2$ : The board of directors has a significant positive effect on firm value.

3. The Relationship between the Audit Committee and Firm Value

The audit committee was formed by the board of commissioners, whose task is to confirm that company reporting is prepared following the Statement of Financial Accounting Standards (SFAS) and the supervision of the company's internal control. Company reporting that is under Indonesian GAAP and effective supervision of internal control by the audit committee can ensure that the company's goals can be achieved to optimally increase firm value. Therefore, this study suggests:

H3: The audit committee has a significant positive effect on firm value.

\section{The Relationship between Institutional Ownership and Firm Value}

Institutional ownership is external share ownership. Those shareholders come from an institution, bank, and others. Their role can encourage increased supervision in the management of the company towards management in achieving maximum corporate value. Based on the explanation above, researchers suggest:

H4: Institutional ownership has a significant positive effect on firm value.

5. The Relationship between Managerial Ownership and Firm Value

Managerial ownership is related to the internal party ownership of the company, especially management. This means that internal shareholders also play an active role in making decisions related to strategies and policies for achieving the company's mission that is oriented towards corporate values. Managerial ownership can reduce expenses in the company's operations, especially agency costs arising from agency problems. With a reduction in agency cost, the maximum increase in firm value will be obtained. Therefore, this study suggests:

H5: Managerial ownership has a significant positive effect on firm value.

6. Stock Returns Moderate the Relationship between the Independent Board of Commissioners and Firm Value

The board of commissioners' task is to supervise the board of directors. With the role of the board of commissioners, it is hoped that they will be able to 
supervise the decisions and policies transparently made by management. This is done so that shareholders get the complete information regarding the return they will receive and this will increase the share price which is a reflection of the company's value. Hence, this study suggests:

H6: Stock returns moderate the relationship of the independent board of commissioners and firm value.

7. Stock Returns Moderate the Relationship between the Board of Directors and Firm Value

One of the agents is the board of directors. They play an important role, one of which is to make decisions and policies in increasing firm value. Without the role of the board of directors, the company's goals will not be achieved. The existence of directors is essential to attract investors to provide capital for the company. Investments made by investors will increase share prices as a measurement for firm value due to high purchasing power. The high share price will be in line with the increase in stock returns received by investors on their investment decisions. Based on that explanation, this study suggests:

H7: Stock returns moderate the relationship of the board of directors and firm value.

8. Stock Returns Moderate the Relationship between the Audit Committee and Firm Value

The audit committee is the supporting organ that ensures that the company's internal control and reporting are properly managed according to standards (Amaliyah \& Herwiyanti, 2019). The audit committee helps the board of commissioners carry out their duties so that the company is managed with the same goals to increase firm value and stock returns. The role of the audit committee will improve the quality of financial reporting and internal control. This will increase public confidence and it will increase investor investment through stock prices so the stock returns obtained are also optimal. Therefore, this study suggests:

H8: Stock returns moderate the audit committee relationship and firm value.

9. Stock Returns Moderate the Relationship between Institutional Ownership and Firm Value

Institutional ownership is shares ownership of institutions, other institutions, and external companies. Institutional ownership can prevent agency problems so that decision-making can be carried out objectively. The role of institutional ownership can reduce agency costs so that it can increase the firm value which will increase stock returns. Hence, this study suggests:

H9: Stock returns moderate the relationship between managerial ownership and firm value.

10. Stock Returns Moderate the Relationship between Managerial Ownership and Firm Value

Internal parties are the board of directors and commissioners who have ownership of a company. Managerial ownership plays a role in reducing agency problems. Moreover, they are also shareholders, so they will carry out a strategy that can increase the stock returns obtained so the firm value will also have an impact through share prices. Therefore, this study suggests:

H10:Stock returns moderate the relationship between institutional ownership and firm value.

\section{METHOD}

This research is a quantitative method. The type of data is secondary data from financial reports and annual reports. Data collection uses data observation from company financial reports and literature studies. The 
population is property and real estate subsector companies listed on the Indonesia Stock Exchange from 2015-2019 with a total of 94 companies. The sampling uses the purposive sampling method that consists of 17 companies. The total sample for this research is 85 samples. Multiple linear regression is used to analyze the data with STATA ver. 16 .

\section{a. Operational Definition and Variable Measurement}

\section{1) Firm Value}

Firm value is an assessment from investors regarding the current and future performance of a company. The value of the company is represented by the share price.

Tobin's Q =

Equity Market Value+Total Liabilities

Total Assets

2) GCG Mechanisms

a) Independent Board of Commissioners

The role of the independent board of commissioners is very important because it is an external party to the company so that in carrying out its duties that do not receive intervention from various parties (Handayani, 2017).

DKI $=$ Number of Independent Commissioners

Total Number of Board Commissioners

b) Board of Directors

The board of directors' job description is to manage the company to generate profits. The function of managing the company by the board of directors is risk management, internal control, communication, and CSR (Hamdani, 2016 p.88).

$\mathrm{DD}=$ Total Number of Directors

C) Audit Committee

An audit committee is formed by a board of commissioners whose task is to carry out examinations of the board of directors and the company's financial reporting.

$\mathrm{KA}=$ Total Number of Audit Committee

d) Institutional Ownership

Institutional ownership has an important role in the supervision of company management (Suhadak et al., 2019).

$\mathrm{KI}=\underline{\text { Institutional Shares Ownership }}$

Number of Shares Outstanding

e) Managerial Ownership Managerial ownership balances the various interests between shareholders and management (Sofiamira \& Asandimitra, 2017).

$\mathrm{KM}=$ Managerial Shares Owned by Management

Number of Shares Outstanding

\section{3) Stock Returns}

Stock returns are the motivation for investors to invest in the company. Stock return is the total return from investment in a certain period (Brigham, 2018 p.410). $E(R i)=R f+\beta i[E(R m-R f)]$

\section{4) Company Size}

Firm size as a controlling variable. Company size is a classification of large, medium, and small companies (Santoso \& Susilowati, 2020). SIZE $=$ Total Assets

\section{b. Multiple Linear Regression Formula Model 1

$$
\begin{aligned}
\text { TOBINSQ }= & a+\beta 1 . \text { DKI }_{i t}+\beta 2 . \mathrm{DD}_{i t}+\beta 3 . \mathrm{KA}_{i t} \\
& +\beta 4 . \mathrm{KI}_{i \mathrm{it}}+\beta 5 . \mathrm{KM}_{\mathrm{it}}+\beta 6 . \mathrm{SIZE}_{\mathrm{it}}+ \\
& \mathrm{e}_{\mathrm{it}}
\end{aligned}
$$

Model 2

$$
\begin{aligned}
\text { TOBINSQ }= & a+\beta 1 . D K I_{i t}+\beta 2 . D_{i t}+\beta 3 . K_{i t}+ \\
& \beta 4 . \mathrm{KI}_{i t}+\beta 5 . \mathrm{KM}_{i t}+\beta 6 . \mathrm{CAPM}_{\mathrm{it}}+ \\
& \beta 7 . \mathrm{CAPM}_{\mathrm{it}}+\beta 8 . \mathrm{CAPM}_{\mathrm{it}}+\beta 9 . \mathrm{CAPM}_{\mathrm{it}} \\
& +\beta 10 . \mathrm{CAPM}_{\mathrm{it}}+\beta 11 . \mathrm{SIZE}_{\mathrm{it}}+\mathrm{e}_{\mathrm{it}}
\end{aligned}
$$




\section{c. Descriptive Statistical Analysis}

The average value of the company in the property and real estate sub-sector companies is 1.2098 , meaning that the company has the potential to increase the share capital so that it will make the result of return greater than the issued assets. The result of descriptive statistical analysis are:

Table 1

Descriptive Statistical Analysis

\begin{tabular}{lccccc}
\hline & Obs & Minimum & Maximum & Mean & Std. Deviation \\
\hline TOBINS Q & 85 & 0,2132 & 5,4021 & 1,2098 & 0,8919 \\
\hline DKI & 85 & 0,2000 & 0,6667 & 0,3758 & 0,0783 \\
\hline DD & 85 & 2,0000 & 8,0000 & 5,0889 & 1,7459 \\
\hline KA & 85 & 2,0000 & 4,0000 & 2,9556 & 0,3941 \\
\hline KI & 85 & 0,0384 & 0,9775 & 0,6627 & 0,2093 \\
\hline KM & 85 & 0,000001 & 0,6473 & 0,0437 & 0,0119 \\
\hline CAPM & 85 & 0,0015 & 0,2505 & 0,0485 & 0,0320 \\
\hline SIZE & 85 & 445.919 .320 .351 & 29.583.829.904.000 & 6.631 .710 .871 .493 & 7.408 .425 .740 .995 \\
\hline \multicolumn{7}{c}{ Source: STATA ver. 16 Output $(2020)$} &
\end{tabular}

\section{d. Panel Data Regression}

This regression is to test a model that will be feasible to use in this study. The data is processed using the STATA ver. 16 which is explained as follows:

Based on Table 2, the Hausman Test, it is known that the prob. value > sig.
Table2

Hausman Test Statistical Results

\begin{tabular}{lc}
\hline Probability & 0,9266 \\
\hline Sig. & 0,05 \\
\hline Source: STATA ver. 16 Output (2020)
\end{tabular}
so that the model chosen in the Hausman test is the Random Effect Model.

a. Normality Test

The normality test using skewness and kurtosis, the results are as follows:

Table 3

Results of Skewness and Kurtosis

\begin{tabular}{lcc}
\hline \multicolumn{1}{c}{ Variable } & Skewness & Kurtosis \\
\hline TOBIN'S Q & 2.2227 & 8.8049 \\
\hline DKI & 0.8620 & 3.7908 \\
\hline DD & -0.0585 & 2.1373 \\
\hline KA & -0.36663 & 5.9849 \\
\hline KI & -1.7786 & 6.0563 \\
\hline KM & 0.9872 & 2.7177 \\
\hline CAPM & 0.0750 & 2.6258 \\
\hline SIZE & 1.9615 & 5.7930 \\
\hline \multicolumn{2}{r}{ Source: STATA ver. 16 Output $(2020)$}
\end{tabular}

Based on Table 3, the skewness value is less than 3 and the kurtosis value is less than 10 (Hamilton, 2013 p.131). So the data is normally distributed. b. Multicolonierity Test

The multicollinearity test using tolerance and VIF 
Table 4

Multicolonierity Test

\begin{tabular}{lcc}
\hline \multirow{2}{*}{ Variable } & \multicolumn{2}{c}{ Collinearity Statistics } \\
\cline { 2 - 3 } & Tolerance & VIF \\
\hline DKI & 1,1600 & 0.8657 \\
\hline $\mathrm{DD}$ & 1,4700 & 0.6809 \\
\hline $\mathrm{KA}$ & 1,1500 & 0.8665 \\
\hline $\mathrm{KI}$ & 1,2200 & 0.8196 \\
\hline $\mathrm{KM}$ & 1,4600 & 0.6866 \\
\hline $\mathrm{CAPM}$ & 1,1400 & 0.8772 \\
\hline SIZE & 1,8800 & 0.5313 \\
\hline Mean VIF & 1,3500 & Mean VIF \\
\hline
\end{tabular}

Source: STATA ver. 16 Output (2020)

Based on Table 4, the multicollinearity test results show that the Tolerance value is more than 0.10 and the VIF is less than 10 (Ghozali, 2018 p.108). The regression model tested was free from multicollinearity assumptions.

Table 5

General Least Square Test Results

\begin{tabular}{llc}
\hline Coefficients & $:$ & $\begin{array}{c}\text { generalized least } \\
\text { squares }\end{array}$ \\
\hline Panels & $:$ & homoskedastic \\
\hline Correlation & $:$ & no autocorrelation \\
\hline \multicolumn{2}{c}{ Source: STATA ver. 16 Output (2020) }
\end{tabular}

Based on Table 5, the output results from the General Least Square (GLS) test show that there are no autocorrelation and heteroscedasticity c. Autocorrelation and Heteroscedasticity Test

The autocorrelation and heterosced asticity tests used the General Least Square (GLS). The results are as follows:

\section{Table 6 \\ Coefficient of Determination for Model 1 and 2

\begin{tabular}{lll}
\hline Model $1:$ & 0,2830 \\
\hline Model $2:$ & 0,3205 \\
\hline Source : STATA ver. 16 Output (2020)
\end{tabular}

Based on Table 6, it is found that the result of Adjusted $R$ Square model 1 before the moderation variable is $28.30 \%$. These results indicate that the firm value variable is explained through the GCG mechanisms as much as problems in this study, so the data is homoskedastic.

\section{f. Hypothesis Testing}

Determination Coefficient Test
$28.30 \%$. While $71.70 \%$ is explained through variables outside this study.

Based on Table 6, it is found that the result of Adjusted R Square model 2 is 0.3205 or equal to $32.05 \%$. These results indicate that the firm value variable is explained through the GCG 
mechanisms as much as $32.05 \%$. While $67.95 \%$ is explained through variables outside this study.

\section{g. Multiple Linear Regression Result}

Table 7

Multiple Linear Regression Test Results Model 1

\begin{tabular}{lcc}
\hline \multirow{2}{*}{ Variable } & \multicolumn{2}{c}{ Regression Model } \\
\cline { 2 - 3 } & \multicolumn{2}{c}{ Random Effect Model } \\
\cline { 2 - 3 } & Coefficients & Prob. \\
\hline (Constant) & $-1,4730$ & 0.2890 \\
\hline DKI & $-1,2217$ & 0,1770 \\
\hline DD & 0,1665 & $0,0380 *$ \\
\hline KA & 0,6119 & $0,0720 * *$ \\
\hline KI & 1,1054 & 0,1350 \\
\hline KM_w & $-0,8505$ & 0,8670 \\
\hline SIZE & $-2,9300$ & 0,2080 \\
\hline Prob. & & \\
$* 0,05$ & & \\
$* * 0,10$ & & \\
\hline
\end{tabular}

Source: STATA ver. 16 Output (2020)

Table 8

Multiple Linear Regression Test Results Model 2

\begin{tabular}{lcc}
\hline \multirow{2}{*}{ Variable } & \multicolumn{2}{c}{ Regression Model } \\
\cline { 2 - 3 } & \multicolumn{2}{c}{ Random Effect Model } \\
\cline { 2 - 3 } & Coefficients & Prob. \\
\hline (Constant) & $-3,9358$ & 0,0360 \\
\hline DKI & $-0,5839$ & 0,7380 \\
\hline DD & 0,1311 & 0,2650 \\
\hline KA & 1,3521 & 0,0110 \\
\hline KI & 1,6345 & 0,0440 \\
\hline KM_W & $-0,9578$ & 0,8520 \\
\hline CAPM & 41,7885 & 0,1290 \\
\hline CAPMDKI & $-13,3477$ & 0,7250 \\
\hline CAPMDD & 0,7216 & 0,6650 \\
\hline CAPMKA & $-10,9503$ & 0,1240 \\
\hline CAPMKI & $-15,6978$ & 0,3250 \\
\hline CAPMKM & $-8,2428$ & 0,6130 \\
\hline SIZE & $-3,1800$ & 0,1330 \\
\hline \multicolumn{2}{c}{ SOUTCe: } &
\end{tabular}

\section{Model 1}

Source: STATA ver. 16 Output (2020)

$$
\begin{aligned}
\text { TOBIN'S }= & -1,4730-1,2217 \mathrm{DKI}+0,1665 \\
& \mathrm{DD}+0,6119 \mathrm{KA}+1,1054 \mathrm{KI}- \\
& 0,8505 \mathrm{KM}-2,9300 \mathrm{SIZE}+\mathrm{e}
\end{aligned}
$$

Model 2

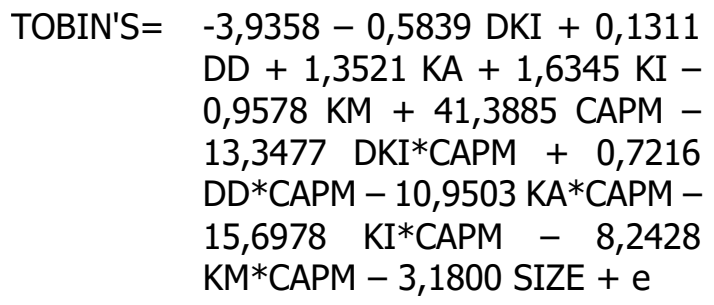

TOBIN'S $=-3,9358-0,5839$ DKI $+0,1311$ $\mathrm{DD}+1,3521 \mathrm{KA}+1,6345 \mathrm{KI}-$ $0,9578 \mathrm{KM}+41,3885 \mathrm{CAPM}-$ 13,3477 DKI*CAPM $+0,7216$ DD*CAPM - 10,9503 KA*CAPM 15,6978 KI*CAPM $-8,2428$ KM*CAPM $-3,1800$ SIZE $+e$ 
RESULTS AND DISCUSSION

1) The Independent Board of Commissioners Has No Effect on Firm Value

The independent board variable has a prob. $0.1770(0.1770>0.05)$, which means $\mathrm{H} 1$ is rejected.

According to the Financial Services Authority

Regulation No.33/POJK.04/2014, independent commissioners can be reappointed after serving for 2 (two) periods as long as they declare that they remain independent to the General Meetings of Shareholders. In the property and real estate sub-sector, on average, the term of the independent board of commissioners is more than 3 years. However, the longer they serve as an independent board of commissioners, the more emotional a relationship will be. It is feared that the term of office will make them not independent. Therefore, independent boards of commissioners who have served too long can affect their independence in overseeing the implementation of GCG in the company.

2) The Board of Directors has a Significant and Positive Effect on Firm Value

The board of directors using the number of boards of directors in the company has a prob. 0.0380 $(0.0380<0.05)$, so $\mathrm{H} 2$ is accepted.

Based on agency theory, shareholders delegate decision-making to company managers. The board of directors has to maintain transparency regarding the company's overall financial report information to shareholders. This is to avoid agency problems that can cause agency costs. Therefore, a large number of boards of directors will make decisions about strategy and policy objectives because of the many experiences of each board of directors, so that the company's going concerned can be guaranteed.

3) The Audit Committee has a Positive Significant Effect on Firm Value
The prob. of the audit committee amounted to $0.0720(0.0720>0.10)$, so H3 was accepted.

The existence of an audit committee is one of the considerations for investors in their investment decisions. This is because the existence of an audit committee will guarantee the credibility of the financial reports published by the company. The financial statements published by the company completely and clearly will attract investors. This is an important factor because the company's financial statements will be an assessment of the company's strategy in the future.

4) Institutional Ownership Has No Effect on Firm Value

Hypothesis testing that has been carried out has the result that institutional ownership as measured by the proportion of institutional ownership has a prob. amounting to $0.1350(0.1350>0.05)$, so $\mathrm{H} 4$ is rejected.

Agency theory suggests that the separation of ownership between principal and agent can cause a conflict of interest. The separation of ownership will create a conflict due to information asymmetry. The existence of information asymmetry can make companies spend money in overcoming these conflicts so that it will have an impact on the decline in company value. Therefore, a large proportion of institutional ownership does not guarantee an increase in firm value because supervision on the opportunistic behavior of managers is still ineffective.

5) Managerial Ownership Has No Effect on Firm Value

Managerial ownership has a prob. level of $0.8670(0.8670>0.05)$, so it rejects $\mathrm{H} 5$.

Based on agency theory, separation of ownership will lead to information asymmetry. This is because managers will have more information than shareholders. With managerial 
ownership, managers will be opportunistic to make decisions by their goals. Management as a shareholder will tend to make decisions according to their wishes, but not necessarily in line with other shareholders.

6) Stock Returns Cannot Moderate the Relationship of the Independent Board of Commissioners and Firm Value

The independent board of commissioners with stock returns moderated has a prob. of 0.7250 $(0.7250>0.05)$, which means that $\mathrm{H} 6$ is rejected.

The rate of return generated by the company is also influenced by several macro and micro factors so that if a global event occurs, it will have an impact on stock returns. This will have an impact on the decline in stock prices which illustrates the value of the company. Agency theory suggests that there is a separation, but problems often arise that will cause agency costs. The role of the independent board of commissioners in monitoring company management does not guarantee an increase in firm value. This is because the independent board of commissioners is the supervisory party, so it does not take part in making decisions about the company's strategy.

7) Stock Returns Cannot Moderate the Relationship between the Board of Directors and Firm Value

The results of the moderation of stock returns on the board of directors have a prob. amounting to 0.6650 $(0.6650>0.05)$ so that $\mathrm{H} 7$ is rejected.

The role of the board of directors in decision-making is very important because it involves the interests of various parties. This is because the board of directors is a delegation of shareholders to make decisions regarding the sustainability of the company. A large number of boards of directors in the company will cause agency problems that will incur certain costs so that the resulting stock returns are not optimal. Besides, evaluation of the main duties and functions of the board of directors will be difficult because of the large number of boards of directors.

8) Stock Returns Cannot Moderate the Relationship between the Audit Committee and Firm Value

Stock returns as a moderating variable on the audit committee have a prob. amounting to 0.1240 $(0.1240>0.05)$. This means that $\mathrm{H} 8$ is rejected.

Stock returns are one of the goals of investors in their investment decisions. A high rate of return does not guarantee that the role of the audit committee is getting better. Even a well-known member of the audit committee will have no impact on the value of the company. This is because investors only see the financial performance and rate of return that the company provides. Meanwhile, company members, such as the audit committee, are the last things seen in the investment decisions made.

9) Stock Returns Cannot Moderate the Relationship between Institutional Ownership and Firm Value

Stock returns which moderate institutional ownership have a prob. of $0.3250(0.3250>0.05)$, so H9 is rejected.

In connection with agency theory, the separation of ownership between principal and agent will lead to information asymmetry. This is because management as an agent knows more about company information. Companies publish financial reports to attract investors. However, there are still many companies that do not publish complete financial reports, so this will be a negative signal. These negative signals make the company's reputation worse, so institutional investors are hesitant to invest in the company. 
10)Stock Returns Cannot Moderate the Relationship between Manager Ownership and Firm Value

Stock returns that moderate managerial ownership has a prob. 0.6130 $(0.6130>0.05)$ so that $\mathrm{H} 10$ is rejected.

According to agency theory, management becomes the manager of the company because of the delegation of authority by shareholders. Management is frequently opportunistic, specifically making policies for their interests so that shareholders' goals will not achieve. Management also has more information than shareholders'. Based on that case, information asymmetry will occur. This information asymmetry is a negative signal, causing shareholders to distrust management. Therefore, information asymmetry can lead to agency costs. Expenditures of these costs can reduce the value of the company which makes stock returns not optimal.

\section{CONCLUSION}

Based on the research results previously described, conclusions can be drawn that:

a)The independent board of commissioners, institutional ownership, and managerial ownership do not affect firm value.b)The board of directors and the audit committee have a significant positive effect on firm value.c) Stock return is not able to moderate the relationship between the GCG mechanisms and firm value.

Future researchers are expected to use subsectors other than property and real estate or all sectors on the IDX. To measure firm value, further researchers are expected to use the Price Earnings Ratio and Price to Book Value. Stock return uses abnormal return and dividend yield. Further researchers are also advised to add ownership structure variables to the GCG mechanisms, namely public ownership and foreign ownership. Also, institutional ownership is divided into domestic and foreign institutions.

\section{REFERENCES}

agustina, R., Titisari, K. H., \& Masitoh, E. (2020). Pengaruh Profitabilitas, Leverage, Ukuran Perusahaan Dan Gcg Terhadap Firm Value. Jurnal IImiah Universitas Batanghari Jambi, 20(1), 179-182. Google Scholar

Amaliyah, F., \& Herwiyanti, E. (2019). Pengaruh Kepemilikan Institusional, Dewan Komisaris Independen, Dan Komite Audit Terhadap Nilai Perusahaan Sektor Pertambangan. Jurnal Akuntansi, 9(3), 187-200. Google Scholar

Bermundo, M. B., Ferrer, R. C., \& Ramirez, F. (2019). The Mediating Effect Of Corporate Social Responsibility And Dividend Policy On The Effect Of Corporate Governance Mechanism On Firm Value Among Publicly Listed Companies In The Philippines. International Journal Of Engineering And Advanced Technology, $8(6$ Special Issues), 602. Google Scholar

Bisnis.Com. (2020). Penuh Tantangan, Ini Prediksi Pertumbuhan Sektor Properti. Google Scholar

Brigham, E. F. (2018). Dasar-Dasar Manajemen Keuangan. Google Scholar

Cnbc Indonesia. (2020). Corona Perparah Perkantoran Dki Makin Kosong, Sewa Diobral! Cnbc Indonesia. Google Scholer

Cnbc International. (2020). The Biggest Us Mall Owner Simon Says Still Looking To Salvage Other Distressed Retailers. Cnbc International. Google Scholar

Cnn Indonesia. (2020). Ihsg Anjlok, Bei Hentikan Sementara Perdagangan Saham. Cnn Indonesia. Google Scholar

Dhamasanti, J. F., \& Sudaryati, E. (2020). The Effect Of Good Corporate Governance And Financial Performance On Corporate Value. International Journal Of Research In Commerce And Management Studies, 2(5), 9-24. Google Scholar

Eisenhardt, K. M. (2018). Agency Theory: An Assessment And Review. 14(1), 57-74. Google Scholar

Fcgi, F. For C. G. (2002). Seri Tata Kelola 
Perusahaan - Corporate Governance (2nd Ed.) Google Scholar.

Ghozali, I. (2018). Aplikasi Analisis Multivariate Dengan Program Ibm Spss 25. Google Scholar

Hamdani. (2016). Good Corporate Governance (Tinjauan Etika Dalam Praktik Bisnis). Mitra Wacana Media.Google Scholar

Hamilton, L. C. (2013). Statistic With Stata: Updated For Version 12 (8th Ed.). Cengage Learning. Google Scholar

Hanafi, \& Mamduh, M. (2008). Manajemen Keuangan (1st Ed.). Bpfe. Google Scholar

Handayani, B. D. (2017). Mekanisme Corporate Governance, Enterprise Risk Management, Dan Nilai Perusahaan Perbankan. Jurnal Keuangan Dan Perbankan, 21(1), 70-81. Google Scholar

Jensen, M. C., \& Meckling, W. H. (1976). Theory Of The Firm: Managerial Behavior, Agency Costs, And Ownership Structure. Journal of Financial Economics, 3(4), 305-360. Google Scholar

Kartikasari, E. D., Hermantono, A., \& Mahmudah, A. (2019). Good Corporate Governance, Dividend, Leverage, And Firm Value. International Research Journal Of Business Studies, 12(3), 301311. Google Scholar
Ross, S. A. (1977). The Determination of Financial Structure: The IncentiveSignaling Approach. The Bell Journal Of Economics, 23-40. Google Scholar

Santoso, A., \& Susilowati, T. (2020). Ukuran Perusahaan Memoderasi Pengaruh Struktur Modal Terhadap Nilai Perusahaan. Adbis: Jurnal Administrasi Dan Bisnis, 13(2), 156-167. Google Scholar

Scott, R. W. (2015). Financial Accounting Theory (7th Ed.). Pearson Prentice Hall. Google Scholar

Sofiamira, N. A., \& Asandimitra, N. (2017). Capital Expenditure, Leverage, Good Corporate Governance, Corporate Social Responsibility: Pengaruhnya Terhadap Nilai Perusahaan. Jurnal Ekonomi Dan Bisnis, 20(2), 191-214. Google Scholar

Spence, M. (1973). Job Market Signaling The Quarterly Journal Of Economics, 87 (3). Mit Press, August, 355, 374. Google Scholar

Suhadak, S., Kurniaty, K., Handayani, S. R., \& Rahayu, S. M. (2019). Stock Return And Financial Performance As Moderation Variables In The Influence Of Good Corporate Governance Towards Corporate Value. Asian Journal of Accounting Research. Google Scholar

\section{Copyright holder:}

Dhea Ramana Putri, Husnah Nur Laela Ermaya, Noegrahini Lastiningsih (2021)

First publication right:

Journal of Social Science

This article is licensed under:

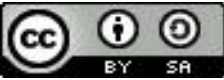

